\author{
JERZY BIELUK ${ }^{1}$
}

\title{
Spółdzielnie rolników - konstrukcja prawna
}

\section{Zagadnienia wstępne}

Spółdzielnie rolnicze są szczególnym typem spółdzielni, których wyróżnikiem jest przede wszystkim przedmiot działalności oraz pewne cechy szczególne wynikające $\mathrm{z}$ regulacji prawnych. W ostatnich latach wyraźnie można dostrzec ożywienie zainteresowania spółdzielczością w rolnictwie, jednak przede wszystkim dotyczy to nie form wspólnego prowadzenia gospodarstwa rolnego, jak w przypadku rolniczych spółdzielni produkcyjnych, ale kooperacji przy organizacji produkcji i sprzedaży - w przypadku spółdzielni mleczarskich.

W polskim rolnictwie ruch spółdzielczy nie jest obecnie znacząco rozwinięty, czego jedną z przyczyn mogą być doświadczenia okresu komunistycznego, związane $\mathrm{z}$ próbami przymusowego wprowadzania gospodarowania kolektywnego ${ }^{2}$. Z ekonomicznego punktu widzenia, wspólne gospodarowanie w wielu przypadkach może przynosić korzyści, również system dystrybucji funduszy unijnych w rolnictwie promuje takie formy działalności. W przyszłości można oczekiwać wzrostu zainteresowania tymi formami prowadzenia działalności rolniczej, zwłaszcza z uwagi na powstanie nowego typu spółdzielni - spółdzielni rolników. Zaś w niektórych sektorach działalności rolniczej spółdzielnie już teraz mają się znakomicie - czego przykładem mogą być spółdzielnie mleczarskie.

Ustawą z dnia 4 października 2018 r. o spółdzielniach rolników³, do polskiego systemu prawnego wprowadzono nową konstrukcję prawną. Jest to interesująca inicjatywa ustawodawcy, która wychodzi naprzeciw współczesnym tendencjom w rozwoju spółdzielczości rolniczej.

\footnotetext{
Uniwersytet w Białymstoku. Publikacja dofinansowana przez Wydział Prawa Uniwersytetu w Białymstoku.

H. Cioch, Prawo spółdzielcze, Warszawa 2011, s. 92.

Dz.U. nr 2073. Dalej: SpółdzRolnU.
} 


\section{Spółdzielnie rolnicze w Polsce}

Ruch spółdzielczy został zapoczątkowany w Polsce w XIX w. i miał na celu przede wszystkim podnoszenie produktywności rolnictwa. W okresie socjalizmu spółdzielczość, jako forma gospodarki uspołecznionej, była promowana przez prawo i władzę jako sposób na stosunkowo bezbolesną (w stosunku do kolektywizacji kołchozowej) formę ograniczenia roli własności prywatnej i budowę nowego ustroju społecznego i gospodarczego ${ }^{4}$. Uspołecznienie rolnictwa w Polsce nie powiodło się, pozostał jednak wyraźny dystans i brak zaufania w stosunku do spółdzielczości, jako modelu, który władza próbowała narzucić polskiej wsi.

Uprzywilejowane miejsce $\mathrm{w}$ gospodarce spółdzielnie straciły po transformacji ustrojowej w 1989 r., wówczas pojawiły się również trudności w ich funkcjonowaniu w warunkach gospodarki rynkowej ${ }^{5}$.

Aktualnie, po wejściu Polski do UE, spółdzielczość przeżywa pewnego rodzaju renesans. W. Dzun, M. Adamski ${ }^{6}$ wskazują, że po okresie kurczenia się spółdzielczości, okres po integracji Polski z UE był dla spółdzielczości rolniczej korzystny, rosły przychody, ale również dochody spółdzielni rolniczych.

\section{Działalność spółdzielni rolniczych w innych krajach europejskich}

Spółdzielnie rolnicze nie są z pewnością przeżytkiem w Europie. W ramach UE przeżywają renesans, specjalizują się, rozszerzają skalę swojego działania. Spółdzielczość doskonale funkcjonuje w krajach Europy Zachodniej, takich jak: Francja, Holandia, Dania, Niemcy ${ }^{7}$. Spółdzielnie rolnicze, między innymi w związku z regulacjami Wspólnej Polityki Rolnej, profesjonalizują się, znacznie wzrasta skala ich działalności, stają się istotnymi graczami rynkowymi, szczególnie w wybranych sektorach rolnictwa, takich jak: mleczarstwo, rynek trzody chlewnej, rynek owoców i warzyw ${ }^{8}$. Taki kierunek rozwoju zbliża je do spółek kapitałowych, oddalając jed-

Zob. A. Suchoń, Prawna koncepcja spółdzielni rolniczych, Poznań 2016, s. 136 i n. Zob. też A. Mickiewicz, B. Mickiewicz, B.M. Wawrzyniak, Charakterystyczne cechy rolniczych spółdzielni produkcyjnych funkcjonujących w latach 1949-2010, „Zagadnienia Doradztwa Rolniczego” 2014, nr 3, s. 51 . O roli spółdzielczości w uspołecznianiu rolnictwa w Polsce zob. m.in. F. Longchamps, Rolnicze spółdzielnie produkcyjne w systemie prawa polskiego, „Państwo i Prawo” 1951, nr 8-9, s. 238 i n.

$5 \quad$ O problemach spółdzielczości po 1989 r. zob. J. Mroczek, Transformacja polskiego sektora spółdzielczego na tle wybranych krajów postsocjalistycznych, „Przegląd Prawniczy, Ekonomiczny i Społeczny” 2012, nr 3, s. 77-86.

6 Spółdzielnie produkcji rolnej przed i po wejściu Polski do UE, „Zagadnienia Ekonomiki Rolnej” 2010, nr 2, s. 60.

7 Zob. D. Mierzwa, Spółdzielczość rolnicza w procesie zmian, (w:) red. nauk. S. Sokołowska, A. Bisaga, Wieś i rolnictwo w procesie zmian. Szanse rozwojowe rolnictwa w przestrzeni europejskiej, Opole 2008, s, 187-188; A. Suchoń, Prawna koncepcja..., op. cit., s. 54-135; tejże, Prawne determinanty rozwoju spółdzielni rolniczych w krajach Unii Europejskiej. Aspekty europejskie, krajowe i regionalne, „Studia luridica Lublinensia” 2017, nr 26, s. 383-398. 
nocześnie od społecznego wymiaru działalności ${ }^{9}$. W pewnych zakresach spółdzielczość wiejska w Europie Zachodniej ma rolę dominującą ${ }^{10}$.

W całej Unii Europejskiej w 2014 r. działało 21.769 spółdzielni rolniczych, ich dochód wynosił 347.342 miliardy euro ${ }^{11}$. Skalę rozwoju spółdzielni europejskich obrazuje również to, że rolnicy w nich zrzeszeni sprzedają 60\% swojej produkcji za ich pośrednictwem. Podobny udział dotyczy eksportu produktów mięsnych, ich przetwórstwa. W niektórych krajach UE udział spółdzielczości w produktach takich jak mleko, wieprzowina czy wino sięga poziomu od 80 do $100 \%{ }^{12}$.

\section{Spółdzielnie rolników}

Spółdzielnie rolników wprowadzone zostały do polskiego prawa ustawą z dnia 4 października 2018 r. o spółdzielniach rolników, która weszła w życie 1 grudnia 2018 r. ${ }^{13}$ Jest to nowa konstrukcja prawna, której przydatność we współczesnej gospodarce rynkowej może być oceniona dopiero w przyszłości.

Zgodnie z intencjami ustawodawcy, ustawa służyć ma wzmocnieniu roli spółdzielczości w rolnictwie i jest odpowiedzią na potrzeby oraz oczekiwania rolników dotyczące wspierania w zrzeszaniu się w spółdzielnie i ich funkcjonowania w takich podmiotach $^{14}$. Sposobem na rozwój tego rodzaju spółdzielczości ma być szereg zachęt, przede wszystkim o charakterze fiskalnym.

Różnice między istniejącymi spółdzielniami, regulowanymi ustawą z dnia 16 września 1982 r. Prawo spółdzielcze ${ }^{15}$ a spółdzielniami rolników mają polegać przede wszystkim na tym, iż te pierwsze obejmują jedynie wybrany zakres działalności - zdefiniowany zarówno dla rolniczej spółdzielni produkcyjnej, jak i dla spółdzielni kółek rolniczych. Nowa regulacja ma dużo szerzej traktować działalność rolniczą prowadzoną wspólnie i odnosić się zwłaszcza do zacieśnienia kooperacji rolników - jak podano w Uzasadnieniu (s. 1), w zakresie np. koncentracji podaży, marketingu, działań optymalizujących koszty produkcji oraz zwiększających dochodowość.

Jak stwierdza się w Raporcie z konsultacji publicznych projektu ustawy o spółdzielniach rolników (s. 2), istotą ustawy jest skoncentrowanie się na wspieraniu wy-

9 W. Czternasty, Determinanty rozwoju spółdzielczości w różnych warunkach ekonomiczno-społecznych, Toruń 2013, s. 210.

10 Zob. również E. Pudełkiewicz, Spółdzielcze formy gospodarowania w Polsce i w innych krajach Europy Zachodniej, „Zeszyty Naukowe SGGW w Warszawie. Polityki Europejskie, Finanse i Marketing” 2009, nr 2 (51), s. 286.

11 Generalny Komitet Spółdzielni Rolniczych Unii Europejskiej - COGECA, Development of Agricultural Cooperatives in the EU, Brussels 2014, s. 23.

12 E. Pudełkiewicz, Spółdzielcze formy..., op. cit., s. 287

$13 \quad$ Z wyjątkiem art. 21, który wszedł w życie z dniem 1 stycznia 2019 r.

14 Zob. s. 1 Uzasadnienia rządowego projektu ustawy o spółdzielniach rolników, druk sejmowy nr 1425, dalej: Uzasadnienie.

15 Tekst jedn. Dz.U. z 2018 r. poz. 1285 z późn. zm. 
twarzania określonego produktu lub grupy produktów, natomiast np. rozszerzenie działalności spółdzielni rolników na świadczenie usług zewnętrznych mogłoby dopuścić możliwość pośredniej formy działalności, odbiegającej od potrzeby tworzenia trwałych więzi wspólnego gospodarowania. Spółdzielnie rolników - w zamiarze ustawodawcy - mają być sposobem na wzmacnianie pozycji producentów rolnych na rynku oraz niwelowanie zagrożeń, jakie przynosi coraz bardziej wymagające otoczenie gospodarcze (s. 2 Uzasadnienia).

W Ocenie skutków regulacji projektu ${ }^{16}$ wskazano, że: Wtasne organizacje gospodarcze pomagajq rolnikom $w$ dostosowaniu produkcji do potrzeb klientów, zdobyciu rynków zbytu, obniżeniu kosztów produkcji, a w efekcie osiagnięciu lepszych efektów ekonomicznych. Dzięki wtaściwemu zorganizowaniu się i dostosowaniu produkcji do wymagań odbiorcy pod względem jakości, ilości i asortymentu, rolnicy zrzeszeni $w$ spótdzielniach rolników sq $w$ stanie sprostać wyzwaniom gospodarki rynkowej przez budowe silnej pozycji wśród uczestników rynku produktów rolnych oraz porzadkowanie relacji w całym łańcuchu żywnościowym, jak również przeciwdziałać spekulacjom na rynkach rolnych. I dalej (s. 2): Zgodnie z danymi Krajowej Rady Spótdzielczej poziom zorganizowania producentów rolnych $w$ spótdzielniach rolników w innych krajach UE jest dużo wyższy niż w Polsce - w Holandii, Irlandii, Francji czy Niemczech wynosi on odpowiednio 98\%, 90\%, 80\% i 70\%, podczas gdy w Polsce kształtuje się na poziomie ok. $15 \%$ (s. 2).

Praktyka pokaże, czy wprowadzona konstrukcja jest potrzebna, jednak z pewnością ułatwienia i ulgi mogą być mechanizmem zachęcającym do utworzenia spółdzielni rolników, m.in. w zakresie udogodnień fiskalnych ( $w$ tym zwolnień z podatku dochodowego od osób prawnych, z podatku od nieruchomości oraz podatku od spadków i darowizn).

\section{Pojęcie spółdzielni rolników}

Zgodnie z art. 4 SpółdzRolnU spółdzielnia rolników jest dobrowolnym zrzeszeniem osób fizycznych lub prawnych prowadzących gospodarstwo rolne w rozumieniu przepisów o podatku rolnym lub prowadzących działalność rolniczą w zakresie działów specjalnych produkcji rolnej, będących producentami produktów rolnych lub grup tych produktów lub prowadzących chów lub hodowlę ryb.

\section{Pojęcie gospodarstwa rolnego}

Przepis art. 4 ust. 1 pkt 1 SpółdzRolnU zawiera odwołanie do gospodarstwa rolnego $\mathrm{w}$ rozumieniu przepisów o podatku rolnym. Zgodnie $\mathrm{z}$ art. 2 ust. 1 ustawy 
z dnia 15 listopada 1984 r. o podatku rolnym ${ }^{17}$ za gospodarstwo rolne uważa się obszar gruntów, o których mowa w art. 1, tj. gruntów sklasyfikowanych w ewidencji gruntów i budynków jako użytki rolne, z wyjątkiem gruntów zajętych na prowadzenie działalności gospodarczej innej niż działalność rolnicza, o łącznej powierzchni przekraczającej 1 ha lub 1 ha przeliczeniowy, stanowiących własność lub znajdujących się w posiadaniu osoby fizycznej, osoby prawnej albo jednostki organizacyjnej, w tym spółki kc. nieposiadającej osobowości prawnej.

Zauważyć należy, iż odwołanie w art. 4 SpółdzRolnU dotyczy definicji podatkowej gospodarstwa rolnego, nie definicji dużo bardziej pasującej do produkcyjnej roli gospodarstwa, czyli definicji z kc., którego art. $55^{3}$ stanowi, że za gospodarstwo rolne uważa się grunty rolne wraz z gruntami leśnymi, budynkami lub ich częściami, urządzeniami i inwentarzem, jeżeli stanowią lub mogą stanowić zorganizowaną całość gospodarczą, oraz prawami związanymi z prowadzeniem gospodarstwa rolnego. Zasadniczą cechą konstrukcji zawartej w ustawie o podatku rolnym jest odwołanie się do wielkości powierzchni gruntów wchodzących w skład gospodarstwa rolnego (minimum 1 ha lub 1 ha przeliczeniowy). Natomiast definicja z kodeksu cywilnego nacisk kładzie na funkcjonalny wymiar gospodarstwa rolnego, określając je jako zorganizowaną całość gospodarczą.

\section{Pojęcie działów specjalnych produkcji rolnej}

Pojęcie działów specjalnych produkcji rolnej - jest pojęciem przede wszystkim podatkowym. Zgodnie z art. 2 ust. 3 ustawy z dnia 26 lipca 1991 r. o podatku dochodowym od osób fizycznych ${ }^{18}$ działami specjalnymi produkcji rolnej są: uprawy w szklarniach i ogrzewanych tunelach foliowych, uprawy grzybów i ich grzybni, uprawy roślin ,in vitro”, fermowa hodowla i chów drobiu rzeźnego i nieśnego, wylęgarnie drobiu, hodowla i chów zwierząt futerkowych i laboratoryjnych, hodowla dżdżownic, hodowla entomofagów, hodowla jedwabników, prowadzenie pasiek oraz hodowla i chów innych zwierząt poza gospodarstwem rolnym. Nie stanowią działów specjalnych produkcji rolnej uprawy, hodowla i chów zwierząt w rozmiarach nieprzekraczających wielkości określonych w załączniku nr 2 do powołanej ustawy ${ }^{19}$.

Tekst jedn. Dz.U. z 2017 r. poz. 1892 z późn. zm.

Tekst jedn. Dz.U. z 2018 r. poz. 1509 z późn. zm.

Szerzej zob. J. Bieluk, Działy specjalne produkcji rolnej. Problemy prawne, Białystok 2013; J. Szlęzak-Matusewicz, P. Felis, Działalność rolnicza a działy specjalne produkcji rolnej - identyfikacja zakresu pojęciowego, (w:) J. Ostaszewski, M. Wrzesiński (red.), Etyka, sprawiedliwość i racjonalność w dorobku nauki o finansach w latach 1918-2018, Warszawa 2018 


\section{Pojęcie produktów rolnych}

Kluczowe dla ustalenia zakresu definicji spółdzielni rolników jest pojęcie produktów rolnych. Zgodnie z art. 6 ust. 6 SpółdzRolnU minister właściwy do spraw rynków rolnych określi, w drodze rozporząazenia, wykaz produktów lub grup produktów, ze względu na które mogą być zakładane spółdzielnie rolników, mając na uwadze znaczenie ekonomiczne poszczególnych produktów rolnych z punktu widzenia krajowej produkcji rolnej oraz chowu lub hodowli ryb. Rozporządzenie Ministra Rolnictwa i Rozwoju Wsi z dnia 28 marca 2019 r. w sprawie wykazu produktów lub grup produktów, ze względu na które mogą być zakładane spółdzielnie rolników ${ }^{20}$, wydane na tej podstawie, określa następujące grupy produktów:

1. Bydło domowe (Bos taurus).

2. Świnie (Sus scrofa).

3. Drób - ptaki gatunku: kura (Gallus gallus) lub kaczka (Anas platyrhynchos), lub kaczka piżmowa (Cairina moschata), lub gęś (Anser anser), lub gęś garbonosa (Anser cygnoides), lub indyk (Meleagris gallopavo), lub przepiórka japońska (Coturnixi japonica), lub perlica (Numida meleagris), lub struś (Struthio camelus).

4. Konie (Equus caballus).

5. Owce (Ovis aries) lub kozy (Capra hircus), lub lamy (Lama glama), lub alpaki (Lama pacos).

6. Króliki (Oryctolagus cuniculus).

7. Nutrie (Myocastor coypus).

8. Szynszyle (Chinchilla lanigera).

9. Jelenie szlachetne (Cervus elaphus) lub jelenie sika (Cervus nippon), lub daniele (Dama dama).

10. Lisy pospolite (Vulpes vulpes) lub lisy polarne (Alopex lagopus), lub norki amerykańskie (Mustela vison), lub tchórze (Mustela putorius), lub jenoty (Nyctereutes procyonoides).

11. Ślimaki z wyłączeniem ślimaków morskich.

12. Jaja ptasie.

13. Mleko.

14. Miód naturalny lub inne produkty pszczele.

15. Kwiaty świeże: cięte lub doniczkowe.

16. Zboża lub rośliny oleiste, lub rośliny bobowate.

17. Buraki cukrowe. 
18. Ziemniaki.

19. Owoce lub warzywa, lub grzyby z rodzaju Agaricus, lub boczniaki, lub shii take, lub inne grzyby uprawne.

20. Liście tytoniu.

21. Szyszki chmielowe.

22. Konopie włókniste lub len.

23. Winogrona świeże inne niż winogrona stołowe.

24. Rośliny przeznaczone do produkcji zielarskiej lub farmaceutycznej.

25. Ozdobne rośliny ogrodnicze.

26. Ryby słodkowodne.

\section{Elementy statutu spółdzielni rolników}

Zakres obowiązkowych regulacji statutu spółdzielni rolników określa art. 5 § 1 Prawa spółdzielczego oraz art. 5 SpółdzRolnU. Łącznie obie regulacje określają następujące obligatoryjne elementy statutu spółdzielni rolników:

1) oznaczenie nazwy z dodatkiem „spółdzielnia” lub „spółdzielczy” i podaniem jej siedziby;

2) przedmiot działalności spółdzielni oraz czas trwania, o ile założono ją na czas określony;

3) wysokość wpisowego oraz wysokość i liczbę udziałów, które członek obowiązany jest zadeklarować, terminy wnoszenia i zwrotu oraz skutki niewniesienia udziału w terminie; jeżeli statut przewiduje wnoszenie więcej niż jednego udziału, może określać ich górną granicę;

4) prawa i obowiązki członków;

5) zasady i tryb przyjmowania członków, wypowiadania członkostwa, wykreślania i wykluczania członków;

6) zasady zwoływania walnych zgromadzeń, obradowania na nich i podejmowania uchwał;

7) zasady i tryb wyboru oraz odwoływania członków organów spółdzielni;

8) zasady podziału nadwyżki bilansowej (dochodu ogólnego) oraz pokrywania strat spółdzielni,

9) warunki przyjmowania do spółdzielni rolników członków będących rolnikami oraz podmiotów niebędących rolnikami;

10) wskazanie minimalnego okresu członkostwa w spółdzielni rolników, który nie może być krótszy niż rok obrotowy; 
11) wskazanie terminu składania przez członka spółdzielni rolników informacji o zamiarze wystąpienia ze spółdzielni rolników, który nie może upływać później niż 3 miesiące przed końcem roku obrotowego;

12) zasady i zakres dostarczania przez członków spółdzielni rolników, w zakresie prowadzonej przez nich działalności, informacji dotyczących w szczególności: powierzchni uprawy, plonów oraz wielkości produkcji produktów lub grup produktów;

13) obowiązujące członków spółdzielni rolników będących rolnikami zasady produkcji produktów lub grup produktów, w tym dotyczące ich jakości i ilości, oraz sposoby ich przygotowywania do zbycia;

14) zasady użytkowania, dzierżawy lub najmu przez spółdzielnię rolników wkładów niepieniężnych oraz sposób ustalania odpłatności za ich użytkowanie, dzierżawę lub najem;

15) rodzaj i zakres odpowiedzialności członków spółdzielni rolników;

16) sankcje wobec członka spółdzielni rolników, który nie wypełnia nałożonych na niego obowiązków statutowych lub nie spełnia wymogów określonych w ustawie, w tym przyczyny wykluczenia i wykreślenia członka spółdzielni rolników z tej spółdzielni;

17) szczegółowy sposób i warunki podziału nadwyżki bilansowej i pokrywania strat;

18) zasady ustalania liczby głosów przysługujących członkom spółdzielni rolników będącym osobami prawnymi - w przypadku niestosowania zasady, o której mowa w art. 36 § 2 zdanie pierwsze Prawa spółdzielczego.

Z uwagi na brzmienie art. 6 ust. 1 SpółdzRolnU - iż przedmiotem działalności spółdzielni rolników jest prowadzenie działalności gospodarczej na rzecz członków spółdzielni rolników w zakresie wyraźnie wskazanych produktów rolnych lub grup produktów, zaś produkty lub grupy produktów, ze względu na które mogą być zakładane spółdzielnie rolników, wynikają z rozporządzenia, to te rodzaje produktów rolnych lub grupy produktów muszą być wyraźnie wskazane w statucie spółdzielni.

\section{Obligatoryjny zakres działalności spółdzielni rolników}

Przedmiotem działalności spółdzielni rolników jest zgodnie z art. 6 ust. 1 SpółdzRolnU prowadzenie działalności gospodarczej na rzecz członków spółdzielni rolników w zakresie:

1) planowania prowadzonej przez rolników produkcji produktów lub grup produktów i dostosowywania jej do warunków rynkowych, ze szczególnym uwzględnieniem jej ilości i jakości; 
2) koncentracji podaży oraz organizowania zbycia produktów lub grup produktów, wyprodukowanych przez rolników;

3) koncentracji popytu oraz organizowania nabycia niezbędnych rolnikom środków do produkcji produktów lub grup produktów.

Są to obligatoryjnie realizowane rodzaje działalności, wyraźnie wskazane przez ustawę. Jednak w przypadku nierealizowania jakiegoś rodzaju działalności wskazanego wyżej trudno wyobrazić sobie jakiekolwiek sankcje, poza przepisem art. 15 SpółdzRolnU, który stanowi, że lustracja, o jakiej mowa w części I tytule I dziale VIII prawa spółdzielczego, jest przeprowadzana również w zakresie spełniania przez spółdzielnię rolników warunków, o których mowa w art. 4-9, a więc także w zakresie przedmiotu działalności określonego w art. 6. Obowiązek przejścia lustracji, do której odnosi się powołany przepis, określa art. $91 \S 1$ prawa spółdzielczego, stanowiąc, że każda spółdzielnia obowiązana jest przynajmniej raz na trzy lata, a w okresie pozostawania w stanie likwidacji corocznie, poddać się lustracyjnemu badaniu legalności, gospodarności i rzetelności całości jej działania.

Z obligatoryjnego wskazania przedmiotu działalności wynikają cele powołania spółdzielni rolników. Wyraźnie wskazuje się tu działania mające za zadanie wykorzystanie efektu skali, aby uzyskać lepsze ceny zarówno przy zbycie produktów rolnych, jak i przy zakupach środków produkcji. Spółdzielnia rolników może wykorzystać swoją silniejszą pozycję negocjacyjną, być równorzędnym partnerem przy negocjacjach zbytu większych ilości produktów rolnych. Powszechną praktyką przedsiębiorców jest tworzenie grup zakupowych, często odrębnych spółek zajmujących się negocjacją i organizacją zakupów większych ilości towarów od producentów. W przypadku analizowanej regulacji tworzy ona podmiot, którego ustawowym zadaniem jest właśnie również pełnienie roli takiej grupy zakupowej, mogącej przy odpowiednio dużym zapotrzebowaniu na środki produkcji negocjować znaczne obniżki cen od dostawców.

Wobec określenia ustawowego, że spółdzielnia rolników winna prowadzić obligatoryjną działalność, wstępna weryfikacja tego warunku powinna nastąpić podczas rejestracji podmiotu w rejestrze przedsiębiorców Krajowego Rejestru Sądowego, przez sąd rejestrowy. $Z$ uwagi na to, że weryfikacji może podlegać jedynie planowany zakres działalności rolniczej, w praktyce nastąpi to na podstawie postanowień statutu w zakresie ustalonego przedmiotu działalności spółdzielni rolników.

\section{Fakultatywny zakres działalności spółdzielni rolników}

W art. 6 ust. 2 SpółdzRolnU wskazano fakultatywne rodzaje działalności spółdzielni rolników. Wskazuje się tu na działalność w zakresie: 
1) przechowywania, konfekcjonowania i standaryzacji produktów lub grup produktów, wyprodukowanych przez rolników;

2) przetwarzania produktów lub grup produktów, wyprodukowanych przez rolników, oraz obrotu uzyskanymi w ten sposób produktami przetworzonymi;

3) świadczenia na rzecz rolników usług związanych z wytwarzaniem przez nich produktów lub grup produktów;

4) zbycia produktów lub grup produktów, wyprodukowanych przez rolników;

5) upowszechniania wśród swoich członków korzystnych dla środowiska metod uprawy, technologii produkcji lub metod gospodarki odpadami;

6) prowadzenia działalności usługowej na rzecz swoich członków innej niż świadczenie usług, o których mowa w pkt 3.

Dodatkowo spółdzielnia rolników może prowadzić również działalność społeczną i oświatowo-kulturalną na rzecz swoich członków i ich środowiska (art. 6 ust. 3 SpółdzRolnU).

Ustawa dopuszcza więc prowadzenie działalności w zakresie usług komplementarnych w stosunku do działalności głównej spółdzielni rolników. Jak wskazuje się w Uzasadnieniu (s. 5): Prezentowane podejście, dookreślajqce zakres dziatań fakultatywnych, wynika z potrzeby skoncentrowania się na wsparciu wszelkich dziatań zwiqzanych z wytwarzaniem określonego produktu lub grupy produktów, co pozwoli na niwelowanie niekorzystnych uwarunkowań polskiego rolnictwa, takich jak rozdrobnienie agrarne $i$ zwiqzane $z$ tym duże rozproszenie podaży produktów oraz ograniczona konkurencyjność.

\section{Rozgraniczenie pomiędzy obligatoryjną i fakultatywną działalnością spółdzielni rolników}

Rozdział pomiędzy działalnością obligatoryjną i fakultatywną może budzić wątpliwości z uwagi na to, iż stanowi on ograniczenie swobody działalności gospodarczej. Zgodnie z art. 22 Konstytucji RP ograniczenie wolności działalności gospodarczej jest dopuszczalne tylko w drodze ustawy i tylko ze względu na ważny interes publiczny. Trudno określić, jaki ważny interes publiczny realizuje ograniczenie swobody wyboru przez spółdzielnię rolników rodzaju prowadzonej działalności. Zwłaszcza że z tego rodzaju ograniczenia nie skorzystano w obowiązującej regulacji dotyczącej rolniczych spółdzielni produkcyjnych. Zgodnie z art. 138 PrSpółdz oprócz działalności głównej, tj. prowadzenia wspólnego gospodarstwa rolnego oraz działalności na rzecz indywidualnych gospodarstw rolnych członków, rolnicze spółdzielnie produkcyjne mogą prowadzić również inną działalność gospodarczą. 
W myśl art. 6 ust. 4 SpółdzRolU przychody z prowadzenia działalności, o których mowa w ust. 2 pkt 6 oraz ust. 3, tj. z prowadzenia działalności usługowej na rzecz swoich członków innej niż świadczenie usług związanych z wytwarzaniem przez nich produktów lub grup produktów oraz działalności społecznej i oświatowo-kulturalnej, nie mogą łącznie przekroczyć $25 \%$ przychodów spółdzielni rolników uzyskanych w danym roku obrotowym.

\section{Podmioty uprawnione do przystąpienia do spółdzielni rolników}

Członkami rolniczych spółdzielni produkcyjnych mogą być wyłącznie osoby fizyczne, natomiast spółdzielnie rolników mogą składać się też z osób prawnych (art. 4 ust. 1 SpółdzRolnU), co należy ocenić pozytywnie. Mogą to być także rolnicze spółdzielnie produkcyjne czy spółdzielnie socjalne prowadzące działalność rolniczą ${ }^{21}$. Członkowie mogą być rolnikami oraz podmiotami niebędącymi rolnikami. Treść statutu może jednak ograniczać prawo tych ostatnich do przystąpienia do spółdzielni lub zastrzec dodatkowe warunki konieczne do spełnienia, aby stać się członkiem (art. 5 ust. 1). Należy zwrócić uwagę na treść art. 7 ust. 2 SpółdzRolnU, który stanowi, że spółdzielnia rolników liczy co najmniej dziesięciu członków będących rolnikami, o ile statut nie wymaga większej liczby członków będących rolnikami. Zatem wymagana jest liczba co najmniej 10 członków rolników. Z Uzasadnienia (s. 5-6): Takie podejście ma na celu zapewnienie trwatej konsolidacji producentów rolnych oraz powstawanie stabilnych i silnych ekonomicznie podmiotów, które, operując na rynku, będq odpowiednim partnerem dla pozostatych uczestników łańcucha żywnościowego. Podmioty te dzięki wtaściwemu zorganizowaniu się również pod względem liczby członków będq w stanie odpowiednio dostosować produkcję do wymagań odbiorcy pod względem jakości, ilości i asortymentu, a także ograniczać koszty produkcji, wykorzystujac efekt skali.

Zgodnie z art. 7 ust. 3 SpółdzRolnU spółdzielnia rolników nie może odmówić przyjęcia w poczet członków rolnika albo podmiotu niebędącego rolnikiem, jeżeli spełnia on wymagania określone w ustawie oraz w statucie. W Uzasadnieniu (s. 6) wskazano, że: Uregulowanie to ma na celu zapewnienie możliwości swobodnego przystępowania rolników oraz podmiotów niebędq̨ych rolnikami do spótdzielni rolników. Spółdzielnia może zatem sprawować kontrolę nad podmiotami przystępującymi w poczet jej członków wyłącznie poprzez określenie warunków przyjęcia obowiązujących wobec wszystkich przyszłych członków.

W myśl art. 8 SpółdzRolnU do rady nadzorczej spółdzielni rolników są wybierani członkowie spółdzielni rolników będący rolnikami. Rozwiązania takie zapewniają, iż decydujący wpływ na działalność spółdzielni rolników będą mieli właśnie

21 A. Suchoń, Uwagi na tle projektu ustawy o spółdzielniach rolników, „Przegląd Prawa Rolnego” 2017, nr 2 (21), s. 201. 
rolnicy, osoby fizyczne lub prawne. Rola członków nierolników jest zmarginalizowana. Przepis art. 8 SpółdzRolnU przewiduje, iż członkami rady nadzorczej spółdzielni mogą być tylko członkowie spółdzielni rolników będący rolnikami. Przepis ten, mimo iż można znaleźć dla niego racjonalne wytłumaczenie, budzi wątpliwości co do zgodności z art. 32 Konstytucji ${ }^{22}$, zgodnie z którym wszyscy są wobec prawa równi, wszyscy mają prawo do równego traktowania przez władze publiczne i nikt nie może być dyskryminowany w życiu politycznym, społecznym lub gospodarczym z jakiejkolwiek przyczyny. W Uzasadnieniu (s. 2-3) wskazuje się, iż przesłankami do wprowadzenia takiego ograniczenia jest zapewnienie rolniczego charakteru spółdzielni i dbałość o interesy rolników. Jednak rozwiązanie to powoduje, iż członkowie spółdzielni nierolnicy nie będą mieli możliwości realizowania funkcji kontrolnych poprzez swego przedstawiciela w radzie nadzorczej, gdyż ustawa im to uniemożliwia. Zgodzić się należy z argumentami, iż: Wyłaczenie z jej (tj. rady nadzorczej - przyp. J.B.) prac członków niebędacych rolnikami może z jednej strony powodować pokrzywdzenie tej kategorii członków (ponieważ utracq możliwość kontrolowania spótdzielni), a z drugiej zmniejszyć efektywność działania spótdzielni, gdyż osoby zasiadajace $w$ radzie będq miały podobne kwalifikacje, a poza tym organem pozostanq osoby o komplementarnych kwalifikacjach. ${ }^{23}$ Podkreślić należy, że w art. 45 prawa spółdzielczego brak jest regulacji wskazujących na takie ograniczenia. Rozwiązanie ustawowe uznać należy za niezgodne z zasadą równych praw i obowiązków członków spółdzielni.

\section{Przynależność do spółdzielni rolników ze względu na rodzaj produktu rolnego}

Zgodnie z art. 6 ust. 5 SpółdzRolnU każdy z członków spółdzielni rolników może przynależeć do jednej spółdzielni rolników w zakresie określonych produktów lub grup produktów. Przepis jest nieprecyzyjny. Interpretować można powyższą regulację w ten sposób, iż rolnik może przynależeć do jednej spółdzielni rolników, prowadzącej działalność w zakresie określonych produktów lub grup produktów, lub w ten sposób, iż rolnik może uznać, że spośród różnych produktów, które wytwarza w gospodarstwie rolnym, w zakresie jednego produktu będzie członkiem jednej spółdzielni rolników, zaś w zakresie drugiego produktu innej spółdzielni rolników.

Spółdzielnie rolników mogą być zakładane nie tylko w zakresie jednego produktu lub grupy produktów (tak w Uzasadnieniu, s. 5). W ich zakresie działalności może być całe spektrum produkcji prowadzonej przez jej członków (określonej w rozporządzeniu Ministra Rolnictwa i Rozwoju Wsi). Powstaje, wobec regulacji 
ustawowej pytanie, czy jeden rolnik może należeć do dwóch spółdzielni rolników, których zakresy się pokrywają, ale deklarować przynależność do jednej w zakresie jednego produktu, a do drugiej w zakresie innego. W Uzasadnieniu (s. 5) wskazano jedynie, że ...istnieje możliwość zatożenia spótdzielni rolników ze względu na więcej niż jeden produkt lub grupę produktów, tak aby objq̨ć wszystkie rodzaje produkcji rolnej prowadzonej przez jej członków. Projektodawca zwraca więc uwagę na dostosowanie zakresu działalności spółdzielni rolników do produktów wytwarzanych przez jej członków, a nie dopuszczalność uczestnictwa producenta w wielu spółdzielniach, w zależności od produktu. W praktyce taka sytuacja, tj. działanie w wielu spółdzielniach, może być pożądana w przypadku producentów różnych produktów, gdyż wyspecjalizowane spółdzielnie ukierunkowane na określony produkt mogą lepiej spełniać swoje zadania. Rozdrobnienie działalności spółdzielni na wiele produktów może nie sprzyjać jej efektywności.

\section{Minimalny okres członkostwa w spółdzielni rolników}

Stosownie do art. 5 ust. 2 SpółdzRolnU obowiązkowym elementem statutu spółdzielni rolników jest wskazanie minimalnego okresu członkostwa w spółdzielni rolników, który nie może być krótszy niż rok obrotowy. Dalej statut powinien również zawierać wskazanie terminu składania przez członka spółdzielni rolników informacji o zamiarze wystąpienia ze spółdzielni rolników, który nie może upływać później niż 3 miesiące przed końcem roku obrotowego. Regulacje te mają wpływać na trwałość członkostwa w spółdzielni rolników. Ich celem może także być zapobieganie wstępowaniu do spółdzielni w celu krótkotrwałego uzyskania korzyści fiskalnych, a nie podjęcia faktycznej współpracy w zakresie działalności rolniczej.

\section{Głosowanie}

Zasadą wynikającą z prawa spółdzielczego określoną w art. 36 § 2 jest to, że każdy członek ma jeden głos bez względu na ilość posiadanych udziałów. Jednak zgodnie ze zdaniem drugim powoływanego przepisu, statut spółdzielni, której członkami mogą być wyłącznie osoby prawne, może określać inną zasadę ustalania liczby głosów przysługujących członkom. W przypadku spółdzielni rolników mamy do czynienia z regulacją ustawową inaczej ustalającą reguły liczenia głosów w przypadku osób prawnych. Zgodnie z art. 7 ust. 4 SpółdzRolnU, jeżeli nie ma zastosowania dyspozytywny przepis art. 36 § 2 PrSpółdz, żaden z członków nie może mieć więcej niż $20 \%$ ogólnej liczby głosów na walnym zgromadzeniu, także pośrednio:

1) przez dysponowanie bezpośrednio lub pośrednio większością głosów na walnym zgromadzeniu, zgromadzeniu wspólników albo walnym zebraniu członków, również jako zastawnik albo użytkownik, bądź w zarządzie 
innej osoby prawnej będącej członkiem spółdzielni rolników, także na podstawie porozumień z innymi osobami;

2) jeżeli członkowie zarządu osoby prawnej będącej członkiem spółdzielni rolników stanowią więcej niż połowę członków zarządu innej osoby prawnej będącej członkiem spółdzielni rolników. Jak jeden członek zarządu to już więcej niż połowa?

Zgodnie z Uzasadnieniem (s. 6): Proponowane regulacje maja na celu wykluczenie możliwości zaburzenia demokratycznego rozkładu głosów oraz nadużywania władzy przez członków spótdzielni rolników w zakresie zarzqdzania działalnościq spótdzielni i jej funkcjonowaniem z uwagi na powiązania pośrednie podmiotów zrzeszonych w takim podmiocie.

\section{Preferencje ekonomiczne}

Do tworzenia i przystępowania do spółdzielni rolników mają zachęcać ulgi ekonomiczne (podatkowe), czyli zwolnienia od podatków dochodowych, lokalnych oraz w podatku od spadków i darowizn.

W myśl art. 4 ust. 1 pkt 3 ustawy z dnia 28 lipca 1983 r. o podatku od spadków i darowizn ${ }^{24}$ zwolnienie od podatku obejmuje nabycie praw do wkładów w spółdzielni rolników, rolniczej spółdzielni produkcyjnej lub w spółdzielni kółek rolniczych. Dalej w ustawie z dnia 12 stycznia 1991 r. o podatkach i opłatach lokalnych ${ }^{25}$ w art. 7 ust. 1 pkt 16 zwalnia się od podatku od nieruchomości budynki i budowle lub ich części oraz zajęte pod nie grunty, wykorzystywane przez spółdzielnię rolników lub związek spółdzielni rolników na działalność określoną w art. 6 ust. 1 i 2 SpółdzRolnU, stanowiące własność albo będące w wieczystym użytkowaniu spółdzielni rolników lub związku spółdzielni rolników, które prowadzą działalność jako mikroprzedsiębiorstwo w rozumieniu załącznika I do rozporządzenia Komisji (UE) nr 651/2014 z dnia 17 czerwca 2014 r. uznającego niektóre rodzaje pomocy za zgodne z rynkiem wewnętrznym w zastosowaniu art. 107 i 108 Traktatu $^{26}$.

Najważniejsza zmiana w ustawach o podatku dochodowym to zwolnienie od podatku dochodowego od osób prawnych dochodów spółdzielni rolników prowadzącej działalność jako mikroprzedsiębiorstwo, pochodzących ze zbycia produktów rolnych lub grup tych produktów, lub ryb, ze względu na które spółdzielnia rolników została założona, wyprodukowanych w gospodarstwach lub działach specjalnych produkcji rolnej jej członków. Takie zwolnienie stanowi znaczne obniżenie kosztów funkcjonowania spółdzielni, dotyczy jednak tylko mikroprzedsiębiorstw, 
tj. przedsiębiorstw, które zatrudniają mniej niż 10 pracowników i których roczny obrót lub roczna suma bilansowa nie przekracza 2 milionów EUR, a zatem spółdzielni o stosunkowo niewielkich przychodach.

\section{Podsumowanie}

Nowa konstrukcja prawna, jaką jest spółdzielnia rolników, to ciekawa od strony praktycznej i teoretycznej propozycja dla rolników, którzy chcą rozwijać swoją działalność. Jej przydatność będzie można ocenić po kilku latach funkcjonowania. $\mathrm{Z}$ pewnością do pozytywów należy zaliczyć ulgi i zwolnienia podatkowe związane $\mathrm{z}$ działalnością prowadzoną przez te podmioty. Może być to impulsem do rozwoju ruchu spółdzielczego w Polsce, podobnie jak ma to obecnie miejsce w krajach zachodnioeuropejskich. 
Keywords: agricultural cooperatives, farmers' cooperative, agricultural holding, agricultural products

Farmers' cooperatives were introduced into Polish legislation by the Act on farmers' cooperatives of 4 October 2018. It is a new legal structure, thus its usefulness for the modern market economy may be assessed only in the future. In accordance with the legislator's intentions, the act aims to strengthen the role of cooperatives in agriculture. It also responds to the needs and expectations of farmers searching for support in the process of their association and functioning in cooperatives. Numerous incentives, mostly of a fiscal nature, are to facilitate the development of this kind of cooperatives. This may be an impulse for the development of the cooperative movement in Poland, as it is currently the case in Western European countries.

\section{Bibliografia:}

Bieluk J., Działy specjalne produkcji rolnej. Problemy prawne, Białystok 2013.

Cioch H., Prawo spółdzielcze, Warszawa 2011.

Czternasty W., Determinanty rozwoju spółdzielczości w różnych warunkach ekonomiczno-społecznych, Toruń 2013.

Dzun W., Adamski M., Spółdzielnie produkcji rolnej przed i po wejściu Polski do UE, „Zagadnienia Ekonomiki Rolnej" 2010, nr 2.

Longchamps F., Rolnicze spółdzielnie produkcyjne w systemie prawa polskiego, „Państwo i Prawo” 1951, nr 8-9.

Mickiewicz A., Mickiewicz B., Wawrzyniak B.M., Charakterystyczne cechy rolniczych spółdzielni produkcyjnych funkcjonujących w latach 1949-2010, „Zagadnienia Doradztwa Rolniczego” 2014, nr 3.

Mierzwa D., Spółdzielczość rolnicza w procesie zmian, (w:) red. nauk. S. Sokołowska, A. Bisaga, Wieś i rolnictwo w procesie zmian. Szanse rozwojowe rolnictwa w przestrzeni europejskiej, Opole 2008.

Mroczek J., Transformacja polskiego sektora spółdzielczego na tle wybranych krajów postsocjalistycznych, „Przegląd Prawniczy, Ekonomiczny i Społeczny” 2012, nr 3.

Pudełkiewicz E., Spółdzielcze formy gospodarowania w Polsce i w innych krajach Europy Zachodniej, „Zeszyty Naukowe SGGW w Warszawie. Polityki Europejskie, Finanse i Marketing” 2009, nr 2 (51).

Suchoń A., Prawna koncepcja spółdzielni rolniczych, Poznań 2016.

Suchoń A., Prawne determinanty rozwoju spółdzielni rolniczych w krajach Unii Europejskiej. Aspekty europejskie, krajowe i regionalne, ,Studia Iuridica Lublinensia” 2017, nr 26.

Suchoń A., Uwagi na tle projektu ustawy o spółdzielniach rolników, „Przegląd Prawa Rolnego” 2017, nr $2(21)$.

Szlęzak-Matusewicz J., Felis P., Działalność rolnicza a działy specjalne produkcji rolnej - identyfikacja zakresu pojęciowego, (w:) J. Ostaszewski, M. Wrzesiński (red.), Etyka, sprawiedliwość i racjonalność w dorobku nauki o finansach w latach 1918-2018, Warszawa 2018. 